\title{
Increasing the Seismic Resistance of Wood-frame Buildings by Applying PU Foam as Thermal Insulation
}

\author{
Wojciech Migda', Marcin Szczepański ${ }^{1}$, Robert Jankowski ${ }^{1 *}$ \\ 1 Gdańsk University of Technology, \\ Faculty of Civil and Environmental Engineering, \\ ul. Narutowicza 11/12, 80-233 Gdańsk, Poland \\ *Corresponding author, e-mail: jankowr@pg.edu.pl
}

Received: 04 December 2018, Accepted: 23 February 2019, Published online: 05 April 2019

\begin{abstract}
Wood-frame buildings are very common in regions that are exposed to earthquakes. Most of residential buildings are constructed using this technology; therefore, the seismic resistance of them is really essential in order to prevent human losses and structural damage. The aim of the present article is to show the results of the detailed numerical FEM analysis focused on the seismic behaviour of the wood-frame house with different in-wall insulation materials. The results of the study clearly indicate that using polyurethane (PU) foam instead of mineral wool leads to the increase in the rigidity of the structure and, therefore, to the substantial reduction in the structural response under different seismic excitations. The results also show that, generally speaking, the level of reduction in the displacement response increases with the increase in the magnitude of the earthquake, which even furthermore benefits the application of PU foam as an insulation material. It has also been concluded that the method of using PU foam can be successfully applied not only in the newly constructed wood-frame houses but also in existing ones since replacing the mineral wool with PU foam is relatively easy and not so much expensive.
\end{abstract}

Keywords

wood-frame buildings, seismic resistance, thermal insulation, PU foam

\section{Introduction}

A lot of structures suffer from damage during major earthquakes as the result of dangerous seismic loads [1-4]. Buildings of high importance, e.g. hospitals, fire departments, crisis management centres are designed in accordance with standards that include different aspects of earthquake risks and adequate preventive measures. Methods of strengthening those structures, mainly build of reinforced concrete and steel frames, are subjected to many studies, including experimental and numerical ones. On the other hand, wood-frame buildings, due to rather low erection cost and their function related mostly to residential housing needs, have not been analysed so intensively. Wood-frame buildings are known to perform relatively well during earthquakes [5-7] and have been analysed in terms of the seismic resistance of individual elements and also their interaction with the whole structure. Even that the research interest dealing with the wood-frame buildings has increased during past decades, one major problem still exists. This problem is related to the cost growth generated by earthquake resistance strengthening in relation to the erection cost, which is much different comparing to the steel-frame and reinforced concrete buildings. Designing special strengthening elements (i.e. base-isolation bearings, structural dampers, anti-seismic units, etc.) in reinforced concrete or steel-frame buildings usually represents a small percentage of the whole erection cost, while similar solutions for wood-frame buildings would increase this percentage significantly what is not efficient from the economical point of view. Therefore, the research on woodframe buildings is often directed towards basic structural elements like shear walls $[8,9]$, methods of anchoring [10], layers/sheathing of walls [11, 12].

Low erection cost is one of the well-known advantages of wood-frame buildings. It results from the fact of rather good availability of the construction material in many parts of the world, ease of erection related to technical aspects (no heavy machinery is required) as well as the erection time and good usability parameters (aesthetics, easy repairs and 
modifications, good climate, etc.). Because of the above issues, wood-frame construction has found many supporters worldwide, in rich countries (e.g. in the USA alone more than $80 \%$ of buildings are wood-frame structures [13]) and also in poorer ones. In many regions exposed to earthquakes (like the west coast of the USA: e.g. San Fernando earthquake of 1971, Loma Prieta earthquake of 1989, Northridge earthquake of 1994; Japan: e.g. Hyogo-ken Nanbu earthquake of 1995 or the Bahamas: e.g. Haiti earthquake of 2010 - to name the most dramatic events causing the loss of human lives) wood-frame buildings present a majority of residential buildings. Therefore, the inexpensive methods of strengthening these buildings are very important to reduce human and economic losses in the future. Moreover, the reconstruction of so many houses damaged during major earthquakes calls for fast, simple, inexpensive and yet safe design, which can be achieved by using wood-frame structures. Such wood-frame buildings can be easily and quickly erected while, at the same time, can be cost effective what is very important for many countries. It could be, for example, applied after the devastating earthquake in the Republic of Haiti in 2010 where a vast number of over 300000 houses collapsed [14] leaving millions of people unsheltered [15].

Apart from other different methods of strengthening of wood-frame buildings, the influence of in-wall insulation has not been study so far from the point of view of seismic resistance. The authors conducted a series of tests and analyses using polyurethane (PU) foam as in-wall insulation and comparing it with the traditional insulation consisting of mineral wool. Some previous results have already been published, including the results from the experimental tests on simple frame element $[16,17]$ and the preliminary results of modal analysis for simplified numerical structural model [18]. The aim of the present article is to show the results of the detailed numerical analysis focused on the seismic behaviour of the wood-frame house insulated with PU foam, as compared to the structural behaviour when mineral wool is used.

\section{Numerical model}

The numerical analysis was carried out using the commercial FEM software Dlubal RFEM. For the purpose of the analysis, a 3D model of a typical single-storey wood-frame house was created, as shown in Fig. 1. The length and width of the building are equal to $12.0 \mathrm{~m}$ and $12.0 \mathrm{~m}$, respectively. The ground floor height is equal to $2.80 \mathrm{~m}$, while the total height is $6.35 \mathrm{~m}$. The walls of the numerical model were created from a number of composite structural elements (see Fig. 2) consisting of four types of shell elements - one representing the wood frame and three representing three layers (two external simulating OSB sheathing and an internal one simulating mineral wool or PU foam). These three layers were fully connected one to another in the case of the panel with PU foam representing the situation when the PU foam is injected inside OSB sheathing and it bonds wooden elements together. On the other hand, a lack of such a connection between the three layers was assumed in the numerical model when mineral wool is used, so as to simulate the situation when mineral wool is only inserted inside OSB sheathing. It should be underlined that such composite elements represent directly the experimental models (see $[16,17]$ for details) of typical wall members in a woodframe building. In addition to the above, standard shell elements were also used to model roof and the slab above the ground floor assuming stiff connections between them in the nodes. The material properties of different elements applied in the numerical study are presented in Table 1.

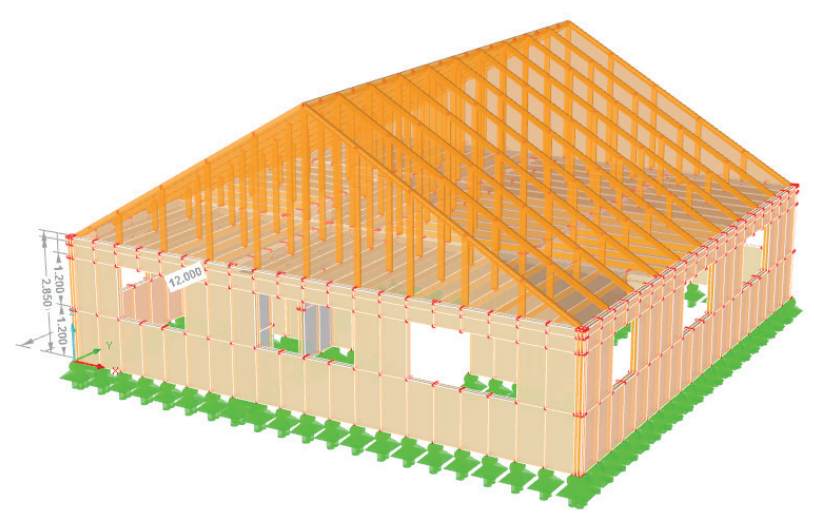

Fig. 1 3D numerical model of a typical wood-frame house

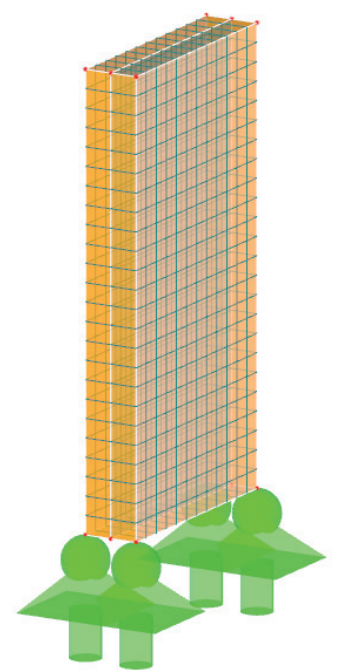

Fig. 2 Composite element with visible 3 layers of shell elements representing OSB sheathing and thermal insulation 
Table 1 Material properties used in the numerical study

\begin{tabular}{lcccc}
\hline Element & Material & $\begin{array}{c}\text { Density } \\
{\left[\mathrm{kg} / \mathrm{m}^{3}\right]}\end{array}$ & $\begin{array}{c}\text { Elasticity modulus } \\
{[\mathrm{GPa}]}\end{array}$ & $\begin{array}{c}\text { Material } \\
\text { model }\end{array}$ \\
\hline Frame & $\begin{array}{c}\text { Wood of } \\
\text { class C24 }\end{array}$ & 509.8 & $\begin{array}{c}11-\text { along fibres } \\
0.37-\text { across fibres }\end{array}$ & $\begin{array}{c}\text { Orthotropic } \\
\text { linear } \\
\text { elastic 2D }\end{array}$ \\
Sheathing & OSB/3 & 713.8 & $\begin{array}{c}1.98-\text { along fibres } \\
4.93-\text { across fibres }\end{array}$ & $\begin{array}{c}\text { Orthotropic } \\
\text { linear } \\
\text { elastic 2D }\end{array}$ \\
Filling 1 & $\begin{array}{c}\text { Mineral } \\
\text { wool }\end{array}$ & 39 & 0.0005 & $\begin{array}{c}\text { Isotropic } \\
\text { linear elastic } \\
\text { Isotropic } \\
\text { Filling 2 }\end{array}$ \\
& PU foam & 26 & 0.01 & $\begin{array}{c}\text { nonlinear } \\
\text { elastic }\end{array}$ \\
\hline
\end{tabular}

\section{Modal analysis}

In the first part of the numerical analysis, the modal analysis has been conducted and the general characteristics (eigenfrequencies and vibration modes) of the building insulated with mineral wool and PU foam have been obtained. The results of the analysis in the form of the first three vibration modes are shown in Figs. 3-5 (building with mineral wool) and in Figs. 6-8 (building with PU foam). Additionally, the eigenfrequencies corresponding to these modes are also summarized in Table 2.

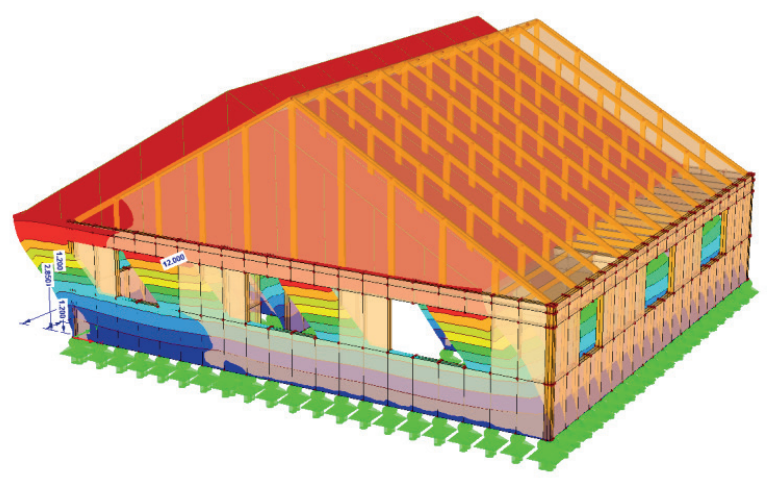

Fig. $31^{\text {st }}$ eigenform for the building with mineral wool

$$
\left(f_{1}=1.890 \mathrm{~Hz}\right)
$$

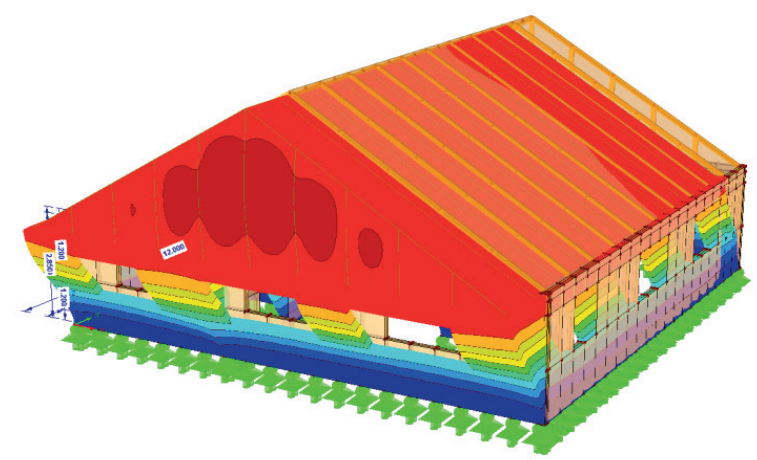

Fig. $42^{\text {nd }}$ eigenform for the building with mineral wool

$$
\left(f_{2}=1.975 \mathrm{~Hz}\right)
$$

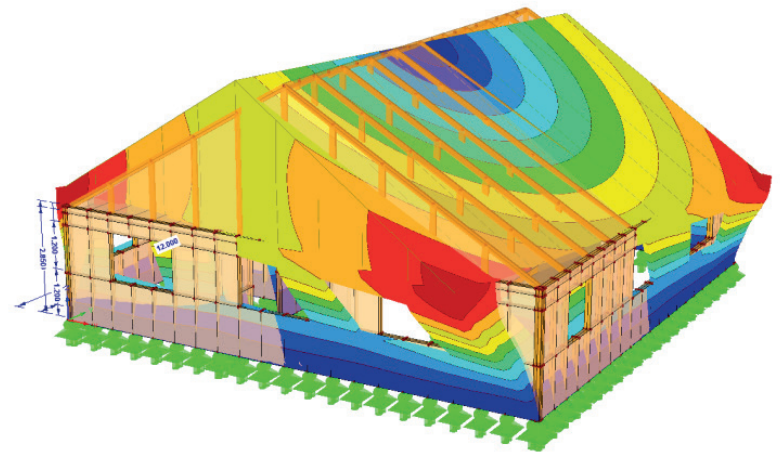

Fig. $53^{\text {rd }}$ eigenform for the building with mineral wool

$$
\left(f_{3}=2.543 \mathrm{~Hz}\right)
$$

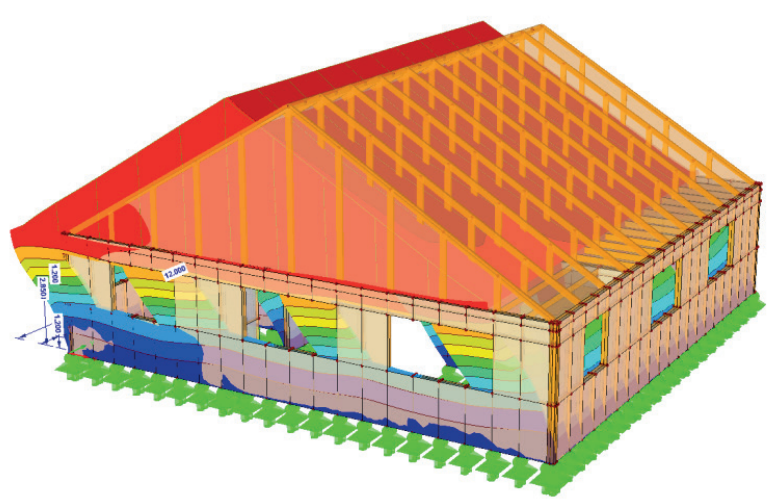

Fig. $61^{\text {st }}$ eigenform for the building with PU foam $\left(f_{1}=3.136 \mathrm{~Hz}\right)$

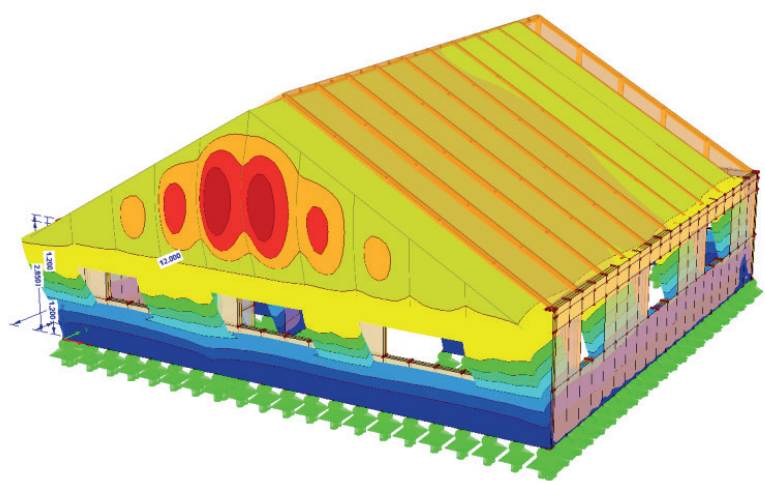

Fig. $72^{\text {nd }}$ eigenform for the building with $\mathrm{PU}$ foam $\left(f_{2}=3.358 \mathrm{~Hz}\right)$

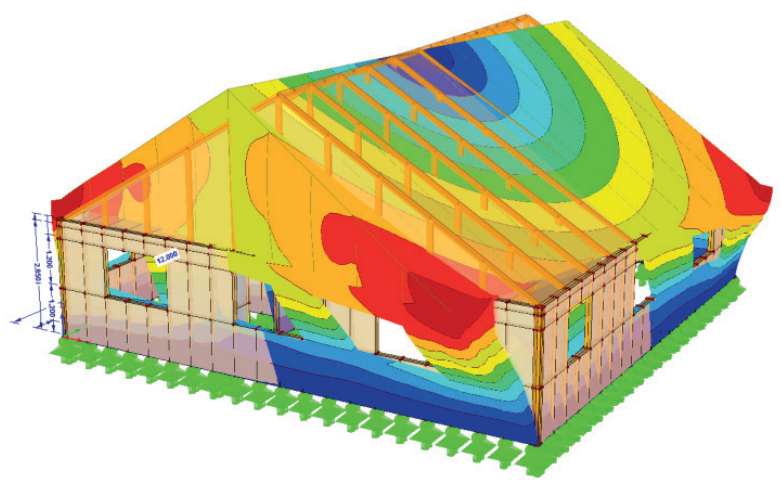

Fig. $83^{\text {rd }}$ eigenform for the building with $\mathrm{PU}$ foam $\left(f_{3}=4.337 \mathrm{~Hz}\right)$ 
Table 2 Eigenfrequencies for building with mineral wool and PU foam

\begin{tabular}{lccc}
\hline $\begin{array}{l}\text { Number of } \\
\text { eigenfrequency }\end{array}$ & $\begin{array}{c}\text { Building with } \\
\text { mineral wool }[\mathrm{Hz}]\end{array}$ & $\begin{array}{c}\text { Building with } \\
\text { PU foam [Hz] }\end{array}$ & $\begin{array}{c}\text { Increase } \\
{[\%]}\end{array}$ \\
\hline 1 & 1.890 & 3.136 & 65.9 \\
2 & 1.975 & 3.358 & 70.0 \\
3 & 2.543 & 4.337 & 70.5 \\
\hline
\end{tabular}

The results of the modal analysis indicate that the vibration modes obtained for the two analyzed structural models are similar, while the values of the natural frequencies are significantly different. As it can be seen from Table 2, the increase in the frequency values of the building insulated with PU foam is as large as nearly $71 \%$, comparing to the structure insulated with mineral wool.

\section{Time history seismic analysis}

In the second part of the study, a time history analyses were conducted under different earthquakes (ground motions used in the dynamic study are described in Table 3, their Fourier spectra are shown in Figs. 9-12). The NS and EW components of the seismic excitations were applied simultaneously for $\mathrm{Y}$ (longitudinal) and $\mathrm{X}$ (transverse) directions of the building, respectively. The time step of each analysis was identical as the time step of the recorded accelerogram, i.e. $0.01 \mathrm{~s}$ for the Tabas and Athens earthquakes, $0.02 \mathrm{~s}$ for the Northridge and Loma Prieta earthquakes. The two ends of the opposite roof eaves as well as both end points of the roof (see Fig. 13) were used as reference nodes so as to compare the results for both numerical models of the building. The examples of the results in the form of displacement and acceleration time histories at the reference nodes for the Loma Prieta earthquake are presented in Figs. 14-29 (similar time histories were obtained for other earthquakes). Moreover, the peak values of displacement and acceleration for all earthquakes are shown in Tables 4-11.

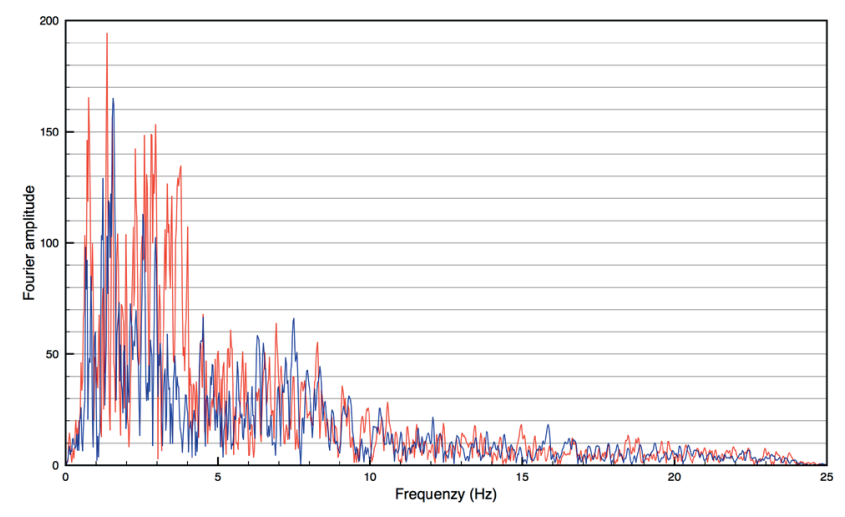

Fig. 9 Fourier spectra for the Loma Prieta earthquake: NS component (blue) and EW component (red)

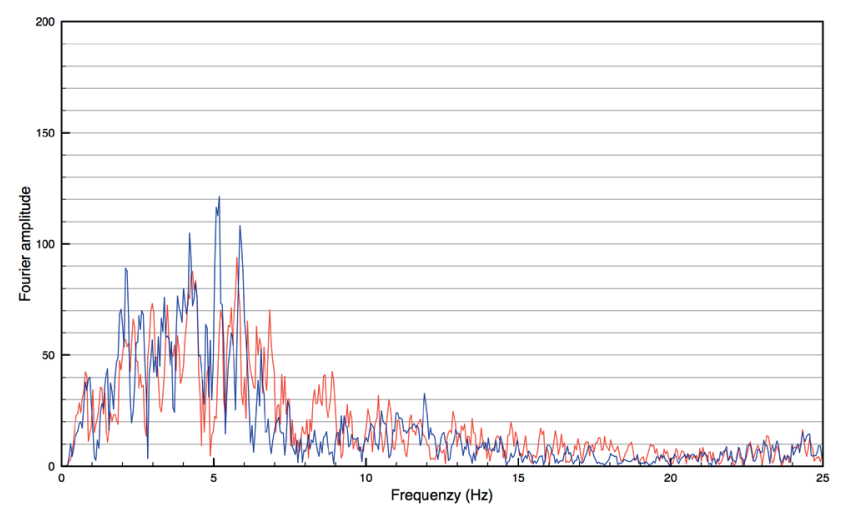

Fig. 10 Fourier spectra for the Athens earthquake: NS component (blue) and EW component (red)

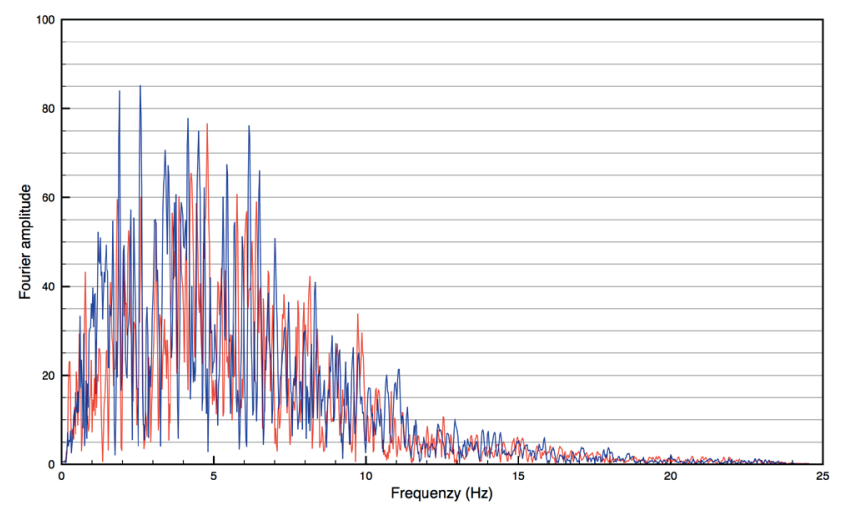

Fig. 11 Fourier spectra for the Northridge earthquake: NS component (blue) and EW component (red)

Table 3 Ground motions used in the dynamic study

\begin{tabular}{|c|c|c|c|c|c|}
\hline Earthquake & Date & Magnitude & Station & Direction & Peak acceleration $\left[\mathrm{m} / \mathrm{s}^{2}\right]$ \\
\hline Loma Prieta & 17.10.1989 & 6.9 & $\begin{array}{c}\text { Capitola - Fire } \\
\text { Station }\end{array}$ & $\begin{array}{l}\mathrm{NS} \\
\mathrm{EW}\end{array}$ & $\begin{array}{l}3.907 \\
4.629\end{array}$ \\
\hline Athens & 07.09.1999 & 6.0 & $\begin{array}{c}\text { Athens - Sepolia } \\
\text { (Garage) }\end{array}$ & $\begin{array}{l}\text { NS } \\
\text { EW }\end{array}$ & $\begin{array}{l}3.045 \\
3.201\end{array}$ \\
\hline Northridge & 17.01.1994 & 6.7 & $\begin{array}{l}\text { Los Angeles - } \\
\text { Obregon Park }\end{array}$ & $\begin{array}{l}\mathrm{NS} \\
\mathrm{EW}\end{array}$ & $\begin{array}{l}3.996 \\
3.478\end{array}$ \\
\hline Tabas & 16.09 .1978 & 7.4 & Tabas & $\begin{array}{l}\text { NS } \\
\text { EW }\end{array}$ & $\begin{array}{l}10.81 \\
9.087\end{array}$ \\
\hline
\end{tabular}




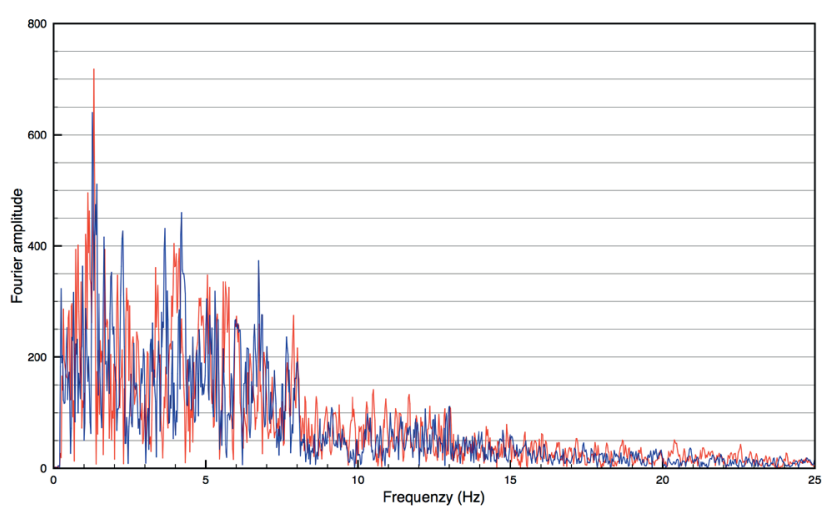

Fig. 12 Fourier spectra for the Tabas earthquake: NS component (blue) and EW component (red)

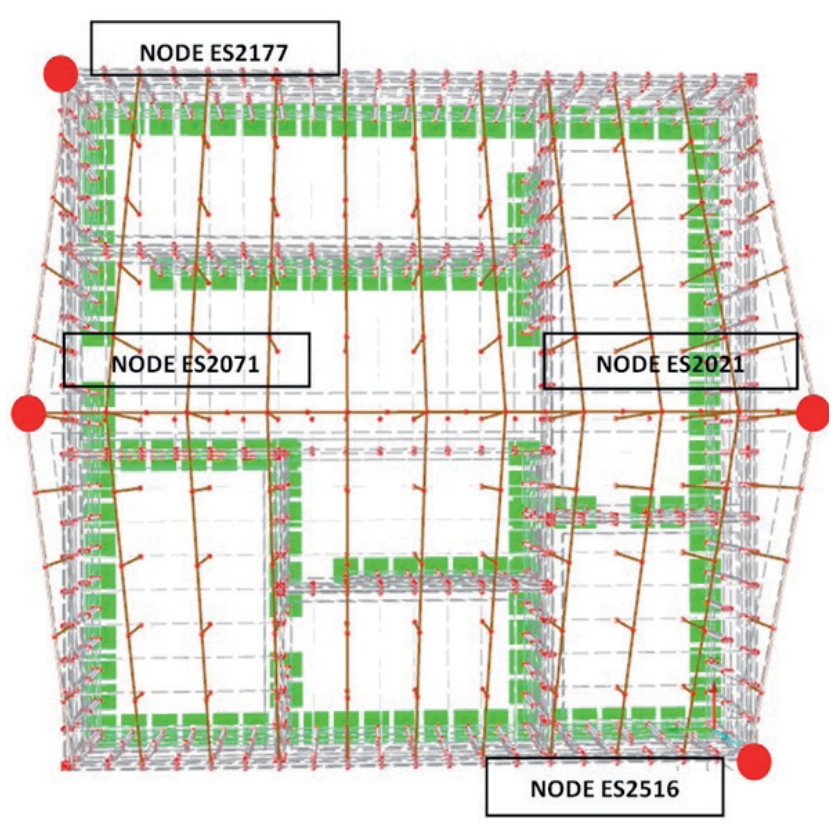

Fig. 13 View of the 3D model from the top showing the reference nodes

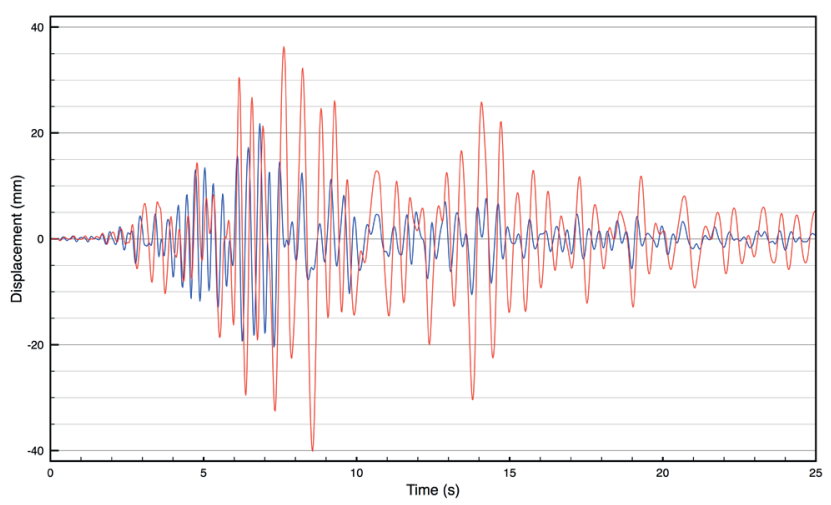

Fig. 14 Displacement time history in X direction for node ES2021 for building with mineral wool (red) and PU foam (blue)

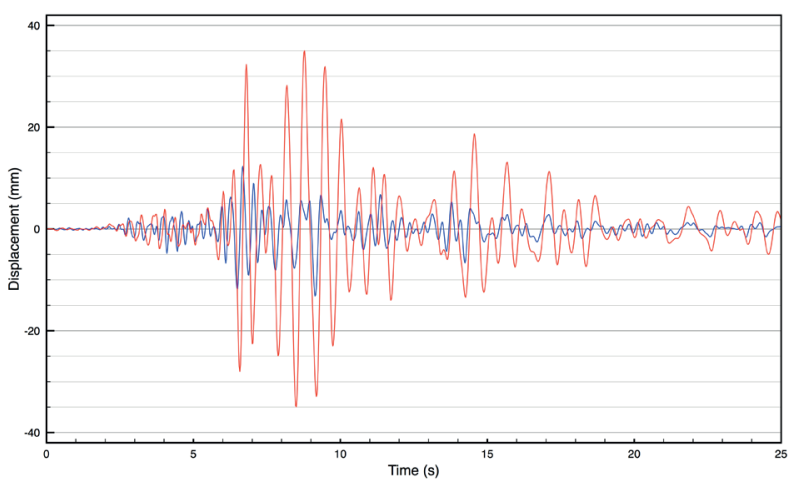

Fig. 15 Displacement time history in Y direction for node ES2021 for building with mineral wool (red) and PU foam (blue)

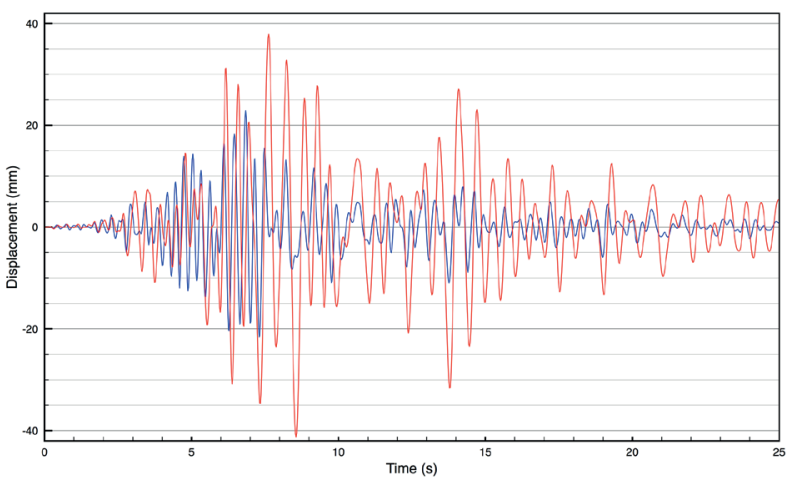

Fig. 16 Displacement time in X direction history for node ES2071 for building with mineral wool (red) and PU foam (blue)

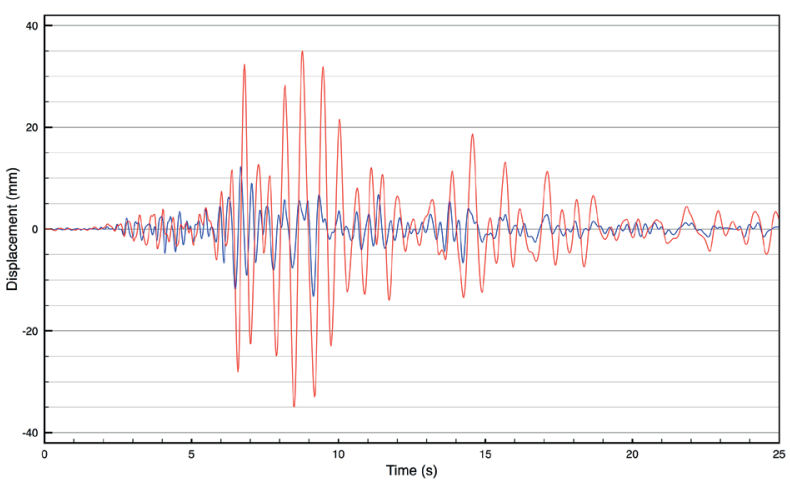

Fig. 17 Displacement time history in Y direction for node ES2071 for building with mineral wool (red) and PU foam (blue)

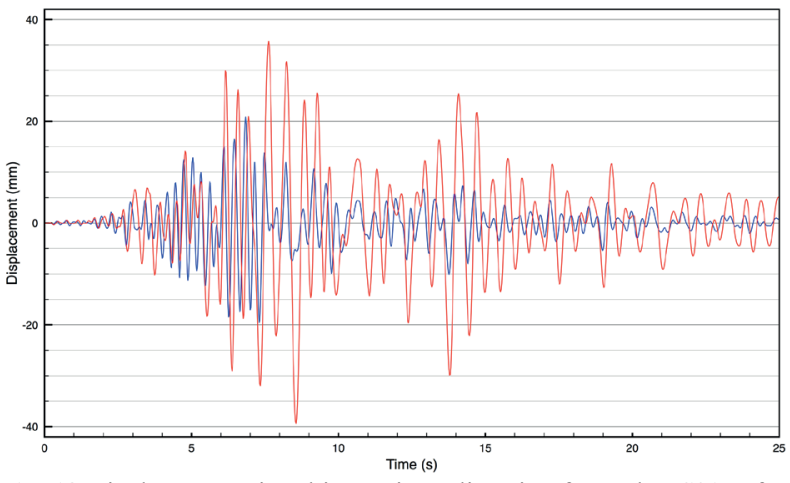

Fig. 18 Displacement time history in X direction for node ES2177 for building with mineral wool (red) and PU foam (blue) 


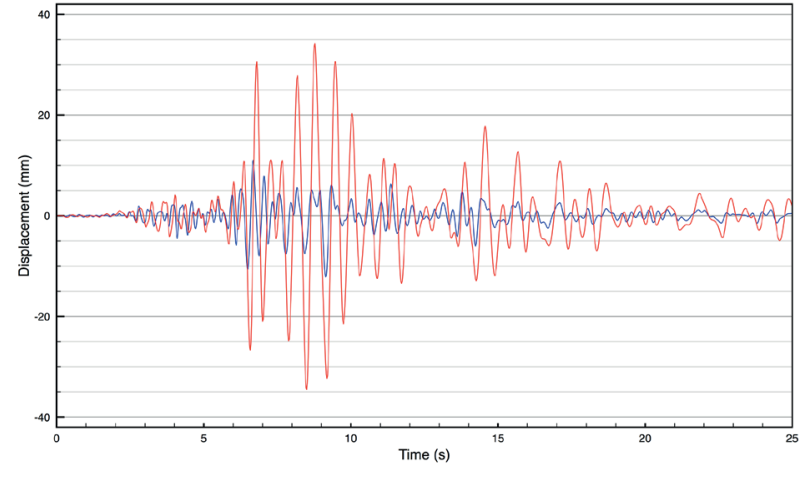

Fig. 19 Displacement time history in Y direction for node ES2177 for building with mineral wool (red) and PU foam (blue)

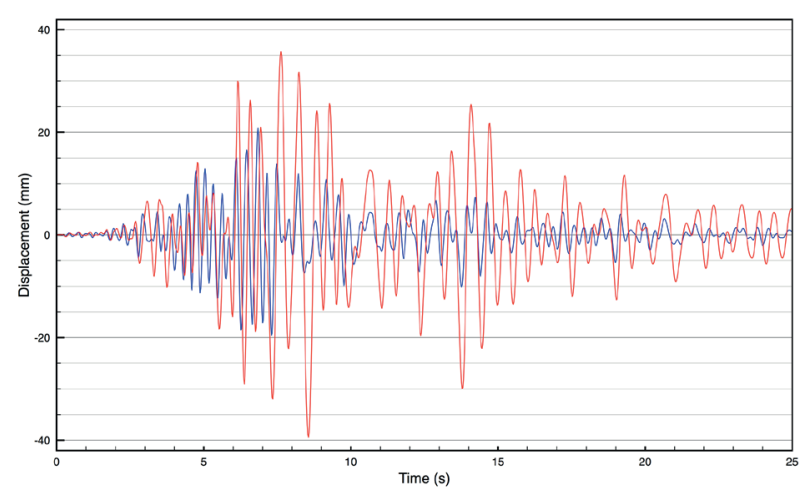

Fig. 20 Displacement time history in X direction for node ES2516 for building with mineral wool (red) and PU foam (blue)

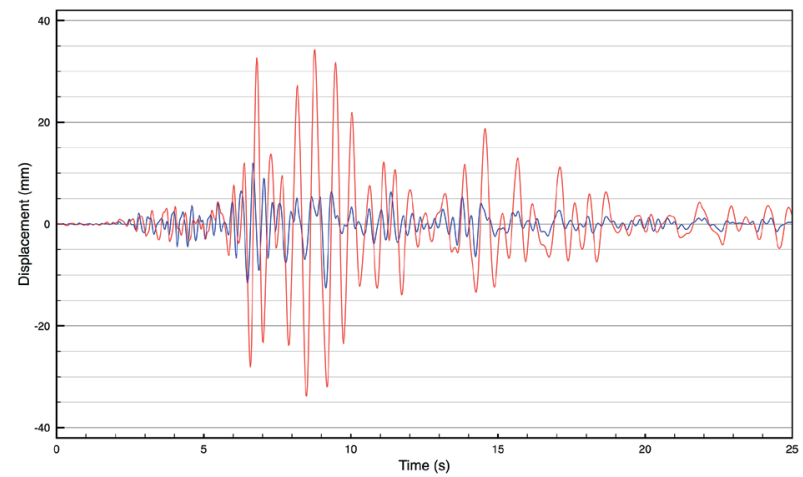

Fig. 21 Displacement time history in Y direction for node ES2516 for building with mineral wool (red) and PU foam (blue)

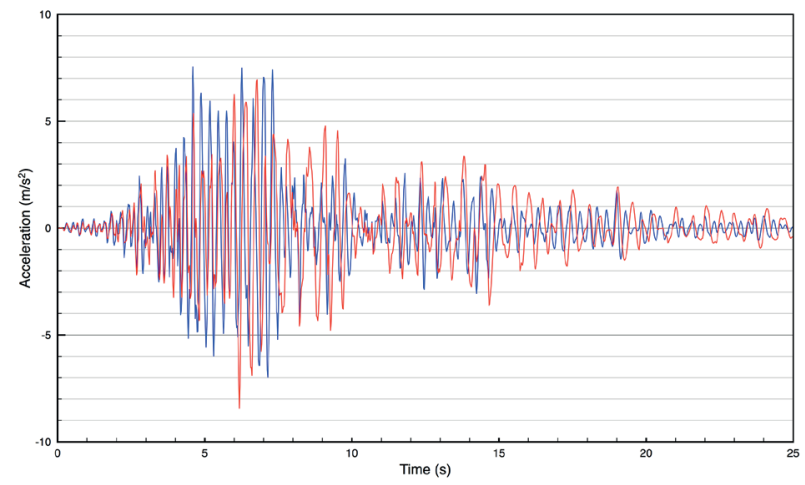

Fig. 22 Acceleration time history in X direction for node ES2021 for building with mineral wool (red) and PU foam (blue)

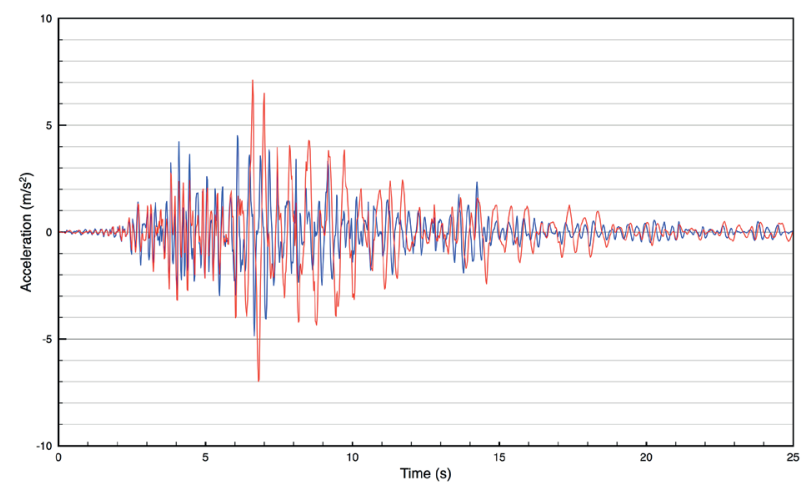

Fig. 23 Acceleration time history in Y direction for node ES2021 for building with mineral wool (red) and PU foam (blue)

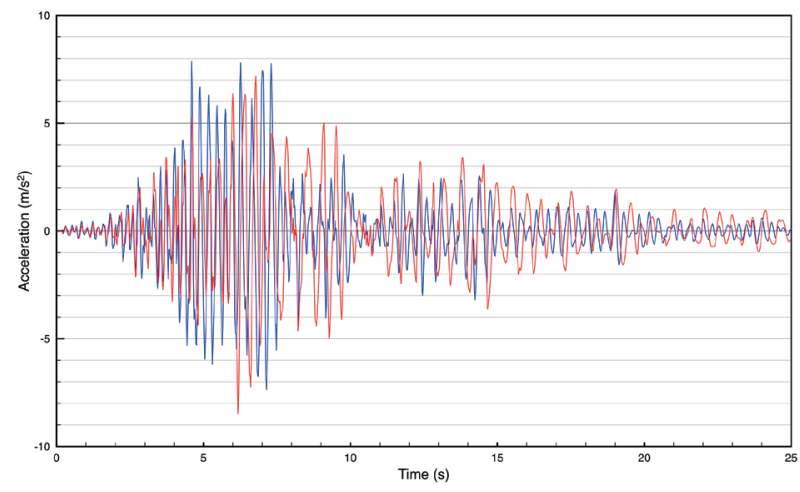

Fig. 24 Acceleration time history in X direction for node ES2071 for building with mineral wool (red) and PU foam (blue)

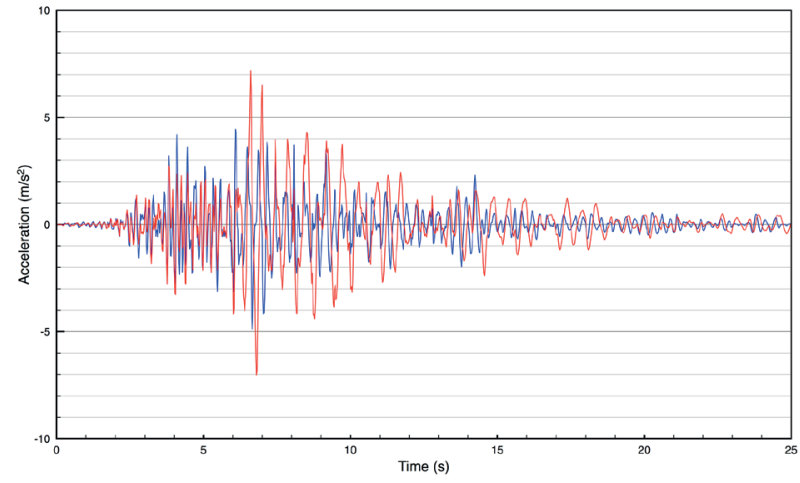

Fig. 25 Acceleration time history in Y direction for node ES2071 for building with mineral wool (red) and PU foam (blue)

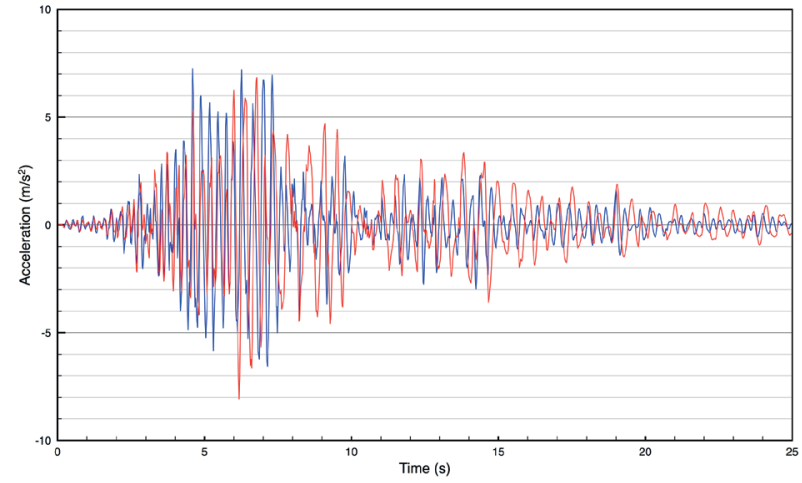

Fig. 26 Acceleration time history in X direction for node ES2177 for building with mineral wool (red) and PU foam (blue) 


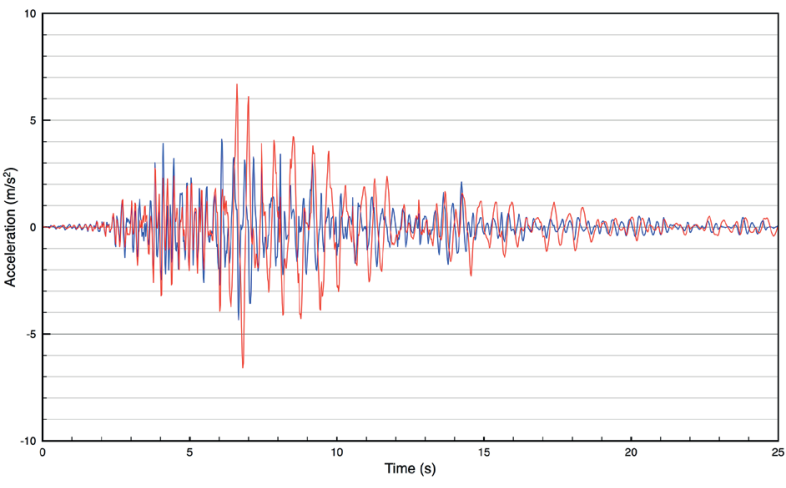

Fig. 27 Acceleration time history in Y direction for node ES2177 for building with mineral wool (red) and PU foam (blue)

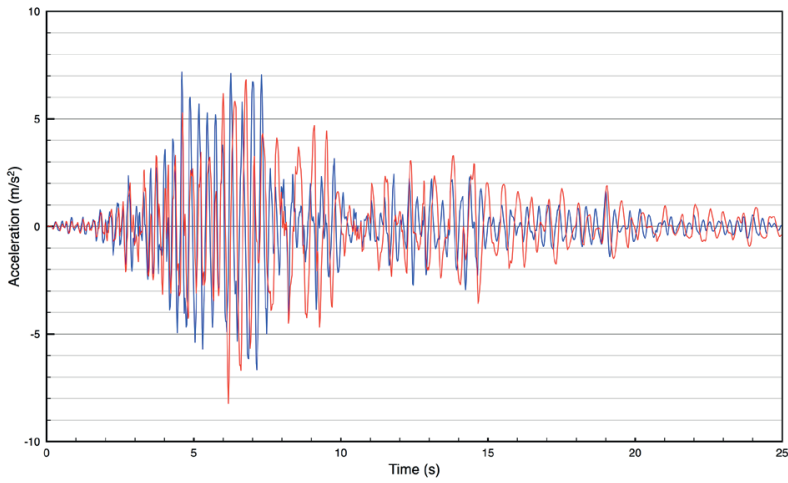

Fig. 28 Acceleration time history in X direction for node ES2516 for building with mineral wool (red) and PU foam (blue)

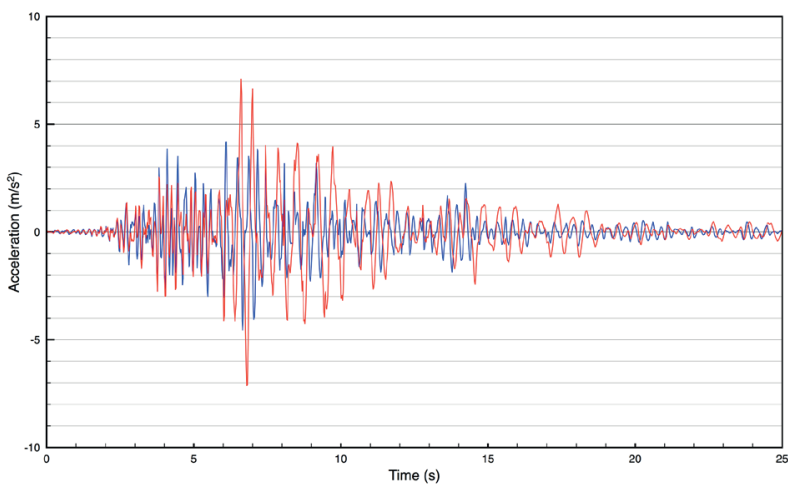

Fig. 29 Acceleration time history in Y direction for node ES2516 for building with mineral wool (red) and PU foam (blue)

Table 4 Peak displacements for node ES2021 for building with mineral

\begin{tabular}{lcccc}
\multicolumn{5}{c}{ wool and PU foam } \\
\hline Earthquake & Direction & $\begin{array}{c}\text { Building with } \\
\text { mineral wool } \\
{[\mathrm{mm}]}\end{array}$ & $\begin{array}{c}\text { Building } \\
\text { with PU foam } \\
{[\mathrm{mm}]}\end{array}$ & $\begin{array}{c}\text { Reduction } \\
{[\%]}\end{array}$ \\
\hline Loma Prieta & $\mathrm{X} / \mathrm{Y}$ & $40.12 / 35.00$ & $21.77 / 13.18$ & $45.7 / 62.3$ \\
Athens & $\mathrm{X} / \mathrm{Y}$ & $16.16 / 23.65$ & $12.97 / 12.55$ & $19.7 / 46.9$ \\
Northridge & $\mathrm{X} / \mathrm{Y}$ & $21.35 / 31.20$ & $7.94 / 18.51$ & $62.8 / 40.7$ \\
Tabas & $\mathrm{X} / \mathrm{Y}$ & $69.07 / 91.69$ & $28.43 / 27.31$ & $58.8 / 70.2$ \\
\hline
\end{tabular}

Table 5 Peak displacements for node ES2071 for building with mineral wool and PU foam

\begin{tabular}{lcccc}
\hline Earthquake & Direction & $\begin{array}{c}\text { Building with } \\
\text { mineral wool } \\
{[\mathrm{mm}]}\end{array}$ & $\begin{array}{c}\text { Building } \\
\text { with PU foam } \\
{[\mathrm{mm}]}\end{array}$ & $\begin{array}{c}\text { Reduction } \\
{[\%]}\end{array}$ \\
\hline Loma Prieta & $\mathrm{X} / \mathrm{Y}$ & $41.26 / 35.00$ & $22.89 / 13.19$ & $44.5 / 62.3$ \\
Athens & $\mathrm{X} / \mathrm{Y}$ & $17.65 / 23.65$ & $12.97 / 12.55$ & $26.5 / 46.9$ \\
Northridge & $\mathrm{X} / \mathrm{Y}$ & $21.98 / 31.21$ & $8.40 / 18.52$ & $61.8 / 40.7$ \\
Tabas & $\mathrm{X} / \mathrm{Y}$ & $71.71 / 91.71$ & $29.98 / 27.30$ & $58.2 / 70.2$ \\
\hline
\end{tabular}

Table 6 Peak displacements for node ES2177 for building with mineral wool and PU foam

\begin{tabular}{lcccc}
\hline Earthquake & Direction & $\begin{array}{c}\text { Building with } \\
\text { mineral wool } \\
{[\mathrm{mm}]}\end{array}$ & $\begin{array}{c}\text { Building } \\
\text { with PU foam } \\
{[\mathrm{mm}]}\end{array}$ & $\begin{array}{c}\text { Reduction } \\
{[\%]}\end{array}$ \\
\hline Loma Prieta & $\mathrm{X} / \mathrm{Y}$ & $39.39 / 34.47$ & $20.81 / 12.15$ & $47.2 / 64.8$ \\
Athens & $\mathrm{X} / \mathrm{Y}$ & $15.88 / 22.75$ & $12.39 / 11.43$ & $22.0 / 49.8$ \\
Northridge & $\mathrm{X} / \mathrm{Y}$ & $20.96 / 30.71$ & $7.59 / 17.54$ & $63.8 / 42.9$ \\
Tabas & $\mathrm{X} / \mathrm{Y}$ & $67.87 / 90.03$ & $27.18 / 26.41$ & $60.0 / 70.7$ \\
\hline
\end{tabular}

Table 7 Peak displacements for node ES2516 for building with mineral wool and PU foam

\begin{tabular}{lcccc}
\hline Earthquake & Direction & $\begin{array}{c}\text { Building with } \\
\text { mineral wool } \\
{[\mathrm{mm}]}\end{array}$ & $\begin{array}{c}\text { Building } \\
\text { with PU foam } \\
{[\mathrm{mm}]}\end{array}$ & $\begin{array}{c}\text { Reduction } \\
{[\%]}\end{array}$ \\
\hline Loma Prieta & $\mathrm{X} / \mathrm{Y}$ & $39.44 / 34.23$ & $20.85 / 12.58$ & $47.1 / 63.2$ \\
Athens & $\mathrm{X} / \mathrm{Y}$ & $15.88 / 22.75$ & $12.43 / 12.06$ & $21.7 / 47.0$ \\
Northridge & $\mathrm{X} / \mathrm{Y}$ & $20.97 / 30.19$ & $7.59 / 17.10$ & $63.8 / 43.4$ \\
Tabas & $\mathrm{X} / \mathrm{Y}$ & $67.88 / 89.04$ & $27.18 / 24.75$ & $60.0 / 72.2$ \\
\hline
\end{tabular}

Table 8 Peak accelerations for node ES2021 for building with mineral wool and PU foam

\begin{tabular}{lcccc}
\hline Earthquake & Direction & $\begin{array}{c}\text { Building with } \\
\text { mineral wool } \\
{\left[\mathrm{m} / \mathrm{s}^{2}\right]}\end{array}$ & $\begin{array}{c}\text { Building } \\
\text { with PU foam } \\
{\left[\mathrm{m} / \mathrm{s}^{2}\right]}\end{array}$ & $\begin{array}{c}\text { Reduction } \\
{[\%]}\end{array}$ \\
\hline Loma Prieta & $\mathrm{X} / \mathrm{Y}$ & $8.43 / 7.10$ & $7.55 / 4.86$ & $10.4 / 31.5$ \\
Athens & $\mathrm{X} / \mathrm{Y}$ & $5.61 / 5.70$ & $5.10 / 5.45$ & $9.1 / 4.4$ \\
Northridge & $\mathrm{X} / \mathrm{Y}$ & $5.97 / 7.82$ & $4.86 / 7.72$ & $18.6 / 1.3$ \\
Tabas & $\mathrm{X} / \mathrm{Y}$ & $13.63 / 21.04$ & $12.67 / 17.80$ & $7.0 / 15.4$ \\
\hline
\end{tabular}

Table 9 Peak accelerations for node ES2071 for building with mineral wool and PU foam

\begin{tabular}{lcccc}
\hline Earthquake & Direction & $\begin{array}{c}\text { Building with } \\
\text { mineral wool } \\
{\left[\mathrm{m} / \mathrm{s}^{2}\right]}\end{array}$ & $\begin{array}{c}\text { Building } \\
\text { with PU foam } \\
{\left[\mathrm{m} / \mathrm{s}^{2}\right]}\end{array}$ & $\begin{array}{c}\text { Reduction } \\
{[\%]}\end{array}$ \\
\hline Loma Prieta & $\mathrm{X} / \mathrm{Y}$ & $8.48 / 7.18$ & $7.88 / 4.88$ & $7.1 / 32.0$ \\
Athens & $\mathrm{X} / \mathrm{Y}$ & $5.93 / 5.73$ & $5.14 / 5.42$ & $13.3 / 5.4$ \\
Northridge & $\mathrm{X} / \mathrm{Y}$ & $5.97 / 7.82$ & $4.91 / 7.70$ & $17.8 / 1.5$ \\
Tabas & $\mathrm{X} / \mathrm{Y}$ & $14.00 / 20.95$ & $12.84 / 17.83$ & $8.3 / 14.9$ \\
\hline
\end{tabular}


Table 10 Peak accelerations for node ES2177 for building with mineral wool and PU foam

\begin{tabular}{lcccc}
\hline Earthquake & Direction & $\begin{array}{c}\text { Building with } \\
\text { mineral wool } \\
{\left[\mathrm{m} / \mathrm{s}^{2}\right]}\end{array}$ & $\begin{array}{c}\text { Building } \\
\text { with PU foam } \\
{\left[\mathrm{m} / \mathrm{s}^{2}\right]}\end{array}$ & $\begin{array}{c}\text { Reduction } \\
{[\%]}\end{array}$ \\
\hline Loma Prieta & $\mathrm{X} / \mathrm{Y}$ & $8.07 / 6.68$ & $7.25 / 4.35$ & $10.2 / 34.9$ \\
Athens & $\mathrm{X} / \mathrm{Y}$ & $5.37 / 5.57$ & $5.02 / 5.00$ & $6.5 / 10.2$ \\
Northridge & $\mathrm{X} / \mathrm{Y}$ & $6.12 / 7.83$ & $4.65 / 7.23$ & $24.0 / 7.7$ \\
Tabas & $\mathrm{X} / \mathrm{Y}$ & $12.87 / 20.51$ & $12.44 / 16.96$ & $3.3 / 17.3$ \\
\hline
\end{tabular}

Table 11 Peak accelerations for node ES2516 for building with mineral wool and PU foam

\begin{tabular}{lcccc}
\hline Earthquake & Direction & $\begin{array}{c}\text { Building with } \\
\text { mineral wool } \\
{\left[\mathrm{m} / \mathrm{s}^{2}\right]}\end{array}$ & $\begin{array}{c}\text { Building } \\
\text { with PU foam } \\
{\left[\mathrm{m} / \mathrm{s}^{2}\right]}\end{array}$ & $\begin{array}{c}\text { Reduction } \\
{[\%]}\end{array}$ \\
\hline Loma Prieta & $\mathrm{X} / \mathrm{Y}$ & $8.22 / 7.12$ & $7.18 / 4.55$ & $12.7 / 36.1$ \\
Athens & $\mathrm{X} / \mathrm{Y}$ & $5.38 / 5.56$ & $5.01 / 5.18$ & $6.9 / 6.8$ \\
Northridge & $\mathrm{X} / \mathrm{Y}$ & $5.90 / 7.69$ & $4.65 / 7.25$ & $21.2 / 5.7$ \\
Tabas & $\mathrm{X} / \mathrm{Y}$ & $13.02 / 20.27$ & $12.46 / 16.14$ & $4.3 / 20.4$ \\
\hline
\end{tabular}

Based on the results obtained (see Figs. 14-29 and Tables 4-11) it can be seen that using PU foam instead of mineral wool leads to the substantial reduction in the response of the analyzed wood-frame building under seismic excitations. The improvement is related to the fact of the increased structural integrity of wall panels due to full connection between PU foam and OSB sheathing. That allows each panel to work as a whole member rather than as a set of independent wooden elements. The effect results in larger values of natural frequencies of the structure (see Table 2) and a shift in the range of predominant frequencies of earthquake excitations (see Figs. 9-12). The improvement in the seismic response of the woodframe building is especially visible in the case of displacements (see the reduction in vibrations during the whole time of the Loma Prieta earthquake in Figs. 14-21). The reduction in the peak displacement is as large as $47.2 \%$ (X direction) and $64.8 \%$ (Y direction) for the Loma Prieta earthquake, $26.5 \%$ (X direction) and $49.8 \%$ (Y direction) for the Athens earthquake, $63.8 \%$ (X direction) and $43.4 \%$ (Y direction) for the Northridge earthquake, $60.0 \%$ (X direction) and $72.2 \%$ (Y direction) for the Tabas earthquake. The results of the study also indicate that, generally speaking, the level of reduction in the displacement response increases with the increase in the magnitude of the earthquake. The largest level of displacement reduction (72.2\%) has been observed for the Tabas earthquake which is the seismic event with the biggest magnitude among all earthquakes considered in the study (see Table 3).
On the other hand, the reduction in the peak acceleration values is smaller (comparing to displacements) but still considerable (see Figs. 22-29). The reduction in the peak acceleration is equal to $12.7 \%$ (X direction) and $36.1 \%$ (Y direction) for the Loma Prieta earthquake, $13.3 \%$ (X direction) and $10.2 \%$ (Y direction) for the Athens earthquake, $24.0 \%$ (X direction) and $7.7 \%$ (Y direction) for the Northridge earthquake, $8.3 \%$ (X direction) and $20.4 \%$ (Y direction) for the Tabas earthquake.

\section{Conclusions}

The behaviour of a typical residential wood-frame building with different in-wall insulation materials has been numerically studied under different earthquake excitations. A modal analysis has been first performed to estimate the dynamic characteristics of the model created. Then, the time history seismic analyses have been conducted and the structural responses of the building insulated with mineral wool and PU foam have been compared.

The results of the study clearly indicate that using PU foam instead of mineral wool for the in-wall insulation of a wood-frame building leads to the increase in the rigidity of the structure. This effect is obtained mainly due to full connection between PU foam and the surrounding wooden elements and a lack of such connection in the case of mineral wool. The increase in the rigidity of the building insulated with PU foam leads to the substantial reduction in the structural response under different seismic excitations. The improvement is especially visible in the case of displacements, for which the largest reductions have been observed. The results of the study also show that, generally speaking, the level of reduction in the displacement response increases with the increase in the magnitude of the earthquake, which even furthermore benefits the application of PU foam as an insulation material.

It has to be underlined that one of the most important factors of using PU foam is the fact that the method can be applied not only in the case of newly constructed buildings. It can also be successfully used in existing woodframe houses since replacing the mineral wool with PU foam is relatively easy and not so much expensive. The results of the study presented in this article clearly show that such an approach would be a very effective method of increasing the seismic resistance of existing structures. 


\section{References}

[1] Migda, W., Jankowski, R. "An approach for the response of buildings subjected to impact load after soft-story failure due to earthquake excitation", Shock and Vibration, 20(4), pp. 681-692, 2013. https://doi.org/10.3233/SAV-130776

[2] Jankowski, R., Mahmoud, S. "Earthquake-induced structural pounding", 1st ed., Springer, Cham, Switzerland, 2015.

https://doi.org/10.1007/978-3-319-16324-6

[3] Jankowski, R. "Theoretical and experimental assessment of parameters for the non-linear viscoelastic model of structural pounding", Journal of Theoretical and Applied Mechanics, 45(4) pp. 931-942, 2007. [online] Available at: http://www.ptmts.org.pl/jtam/index. php/jtam/article/view/v45n4p931 [Accessed: 03.04.2019]

[4] Jankowski, R., Mahmoud S. "Linking of adjacent three-storey buildings for mitigation of structural pounding during earthquakes", Bulletin of Earthquake Engineering, 14(11) pp. 3075-3097, 2016. https://doi.org/10.1007/s10518-016-9946-Z

[5] Mostafaei,H.,Al-Chatti, Q.,Popovski, M., Tesfamariam, S. Bénichou, N. "Seismic performance of wood mid-rise structures", National Research Council Canada, Ottawa, Canada, Rep. RR-345, 2013. https://doi.org/10.4224/21268917

[6] Rainer, J. H., Karacabeyli, E. "Performance of wood-frame construction in earthquakes", presented at 12th World Conference on Earthquake Engineering, Auckland, New Zeland, January 30 February 4, 2000. [online] Available at: https://www.iitk.ac.in/nicee/ wcee/article/2454.pdf [Accessed: 03.04.2019]

[7] Rainer, J. H., Lepper, P., Karacabeyli, E. "Seismic performance of conventional wood-frame buildings", presented at 13th World Conference on Earthquake Engineering Vancouver, Vancouver, Canada, August, 1-6, 2004. [online] Available at: http://www.iitk. ac.in/nicee/wcee/article/13_3195.pdf [Accessed: 03.04.2019]

[8] Yamaguchi, N., Minowa, C., Miyamura, M. "Seismic performance of wooden shear walls on dynamic condition", presented at 12th World Conference on Earthquake Engineering, Auckland, New Zeland, January 30 - February 4, 2000. [online] Available at: http:// www.iitk.ac.in/nicee/wcee/article/0877.pdf [Accessed: 03.04.2019]

[9] Varoglu, E., Karacabeyli, E., Stiemer, S., Ni, C., Buitelaar, M., Lungu, D. "Midply Wood Shear Wall System: Performance in Dynamic Testing", Journal of Structural Engineering, 133(7), pp. 1035-1042, 2007. https://doi.org/10.1061/(ASCE)0733-9445(2007)133:7(1035)

[10] White, K. B. D., Miller, T. H., Gupta, R. "Seismic performance testing of partially and fully anchored wood-frame shear walls", Wood and Fiber Science, 41(4) pp. 396-413, 2009. [online] Available at: https://wfs.swst.org/index.php/wfs/article/view/358/358 [Accessed: 03.04.2019]

[11] Yamada, M., Suzuki, Y., Gotou, M. "Seismic performance evaluation of Japanese wooden frames", presented at 13th World Conference on Earthquake Engineering, Vancouver, Canada, August 1-6, 2004. [online] Available at: http://www.iitk.ac.in/ nicee/wcee/article/13_753.pdf [Accessed: 03.04.2019]

[12] Memari, A. M., Solnosky, R. L. "In-plane Shear Performance of Wood-Framed Drywall Sheathing Wall Systems under Cyclic Racking Loading", Open Journal of Civil Engineering, 4(1), pp. 54-70, 2014. https://doi.org/10.4236/ojce.2014.41006
[13] Liang, H., Wen, Y.-K., Foliente, G. C. "Damage Modeling and Damage Limit State Criterion for Wood-Frame Buildings Subjected to Seismic Loads", Journal of Structural Engineering, 137(1), pp. 41-48. 2011 https://doi.org/10.1061/(ASCE)ST.1943-541X.0000272

[14] Des Roches, R., Comerio, M., Eberhard, M., Mooney, W., Rix, G. J. "Overview of the 2010 Haiti earthquake", Earthquake Spectra, 27(S1), pp. S1-S21, 2011. https://oi.org/10.1193/1.3630129

[15] Rathje, E. M., Bachhuber, J., Dulberg, R., Cox, B. R., Kottke, A., Wood, C., Green, R. A., Olson, S., Wells, D., Rix, G. "Damage patterns in port-au-prince during the 2010 Haiti earthquake", Earthquake Spectra, 27(S1), pp. S117-S136, 2011. https://doi.org/10.1193/1.3637056

[16] Szczepański, M., Migda, W., Jankowski, R. "Timber-frame house resistant to dynamic loads - analysis of wall panel filled with polyurethane foam", Vibrations in Physical Systems, 27, pp. 347-354, 2016. [online] Available at: http://vibsys.put.poznan.pl/ journal/2016-27/articles/vibsys_2016-ch44.pdf [Accessed: 03.04.2019]

[17] Szczepański, M., Migda, W., Jankowski, R. "Construction technology of timber-frame houses resistant to dynamic loads - study on models of exterior walls", Advances in Science and Technology Research Journal, 9(28), pp. 75-80, 2015. https://doi.org/10.12913/22998624/60787

[18] Szczepański, M., Migda, W., Jankowski, R. "Modal analysis of real timber frame houses with different insulation materials", Advances in Science and Technology Research Journal, 10(31), pp. 215-221, 2016.

https://doi.org/10.12913/22998624/64014 